\title{
Analysis of Domestic Wastewater Management Systems in Low Income Residential Areas
}

\author{
Dody Eko Prasetyo*, Heni Fitriani, Betty Susanti \\ ${ }^{l}$ Faculty of Engineering, Civil Engineering Department, University of Sriwijaya, Palembang Region, Indonesia. \\ *Corresponding author email: dody_ep@yahoo.com
}

\begin{tabular}{llll} 
Article history & & \\
\hline Received & Received in revised form & Accepted & Available online \\
30 July 2020 & 21 August 2020 & 31 August 2020 & 31 August 2020
\end{tabular}

\begin{abstract}
Statistically, access to proper sanitation in Muara Enim Regency reaches $90.75 \%$ in 2018, but it needs to be ascertained whether it is safe in the context of no latrine leak that can pollute the environment, especially in areas with the lowest level of population welfare. Muara Lawai village is the village that has the highest number of poor and near poor people and villages with status as underdeveloped village in Muara Enim District. Based on an analysis of existing conditions, the facilities for wastewater sanitation infrastructure used by low-income communities (LIC) and non-LIC in Muara Lawai Village were found to be still not feasible and safe. Efforts to provide adequate and safe sanitation infrastructure that can be implemented in Muara Lawai Village are off-site domestic settlement wastewater system. With initial service coverage for 41 households or 205 people, total wastewater generation $\left(\mathrm{Q}_{\mathrm{r}}\right) 16.40 \mathrm{~m}^{3} /$ day with peak discharge $\left(\mathrm{Q}_{\text {peak }}\right)$ of $54.82 \mathrm{~m}^{3} /$ day, minimum discharge $(\mathrm{Q}$ min) $2.33 \mathrm{~m}^{3} /$ day and infiltration discharge $\left(\mathrm{Q}_{\text {inf }}\right) 12.96 \mathrm{~m}^{3} /$ day, so the design discharge is obtained at $67.78 \mathrm{~m}^{3} /$ day. Calculation results in the service sub-system required a special PVC waste pipe with a roughness value (manning) of 0.012 with details of house connections pipe size $4 "$ along $378.4 \mathrm{~m}$, service pipe size 6" along 167.4 $\mathrm{m}$ and main pipe size 8 "along $67.8 \mathrm{~m}$. The need for control tubs is 31 units installed at each pipe meeting with a size of $50 \times 50 \mathrm{~cm}$. In the processing sub-system (WWTP building), the processing technology used is anaerobic biofilter with the overall dimensions of the WWTP building of $7.5 \times 2.0 \times 2.5 \mathrm{~m}$.
\end{abstract}

Keywords: Domestic Wastewater Treatment System, LIC

\section{Introduction}

Sanitation [1] is an effort to guarantee and improve environmental sanity in a residential area, including collection, treatment and disposal of wastewater, waste and drainage. Unhealthy sanitation in humans can causes iron deficiency, cognitive developmental disorders and stunting in children [2]. Waste management problems that often occur in low and middle-income countries are caused by a lack of skilled local technicians, institutional capacity, and finance [3]. The typical low sanitation in South Sumatra Province is dominated by the characteristics of people with low welfare who live in densely populated areas and with unclean and unhealthy living habits which become their culture [4]. However, the community is very eager to change their sanitation infrastructure to be healthy and decent, but is constrained by knowledge and inability to finance it [5].

Statistically, the indicator of sanitation feasibility is measured by the percentage of households that have access to adequate sanitation, namely access to wastewater management in the form of healthy latrines using goose neck closet and feces disposal sites using septic tanks or domestic wastewater treatment systems. Access to proper sanitation in Muara Enim
District has been very good, reaching $90.75 \%$ in 2018 [4]. From around 578,897 population of Muara Enim Regency, there are still around 53,547 people or $9.25 \%$ who do not yet have access to proper sanitation [4].

Muara Enim District as the capital of Muara Enim Regency has the highest population and population density out of the 20 Districts in Muara Enim Regency [4]. Muara Lawai Village in Muara Enim Subdistrict is the village with the highest number of Poor and Near Poor Families in Muara Enim District which is $72.48 \%$ [5].

Previous studies in this field showed healthy lifestyle with regard to environmental sanitation needs important attention, especially for densely populated areas with low economic levels [6]. The results explained that communal wastewater treatment plants in densely populated areas with low economic levels can improve living standards. A study [7] in a densely populated residential area and located on the banks of a river, found that about $93 \%$ of households already have a walking closet (WC) and $83 \%$ already have a septic tank. But the problem is that the septic tank is never sucked up. The communal waste water treatment plant (WWTP) planning program is offered to the community and around $72 \%$ of households approve the 
communal WWTP program. Research gap remains with regards to the ascertain whether the data stating that access to proper sanitation reaching $90.75 \%$ eligible is actually feasible. If it is not, what is the solution so that the septic tank is safe and suitable for low-income community (LIC) areas.

For this reason, the aim of this study is to analyzed the existing conditions of sanitation in Muara Lawai Village, which then analyzed the technology selection and provision of domestic wastewater treatment system that is suitable for the typical conditions above. The scope of this study is focused on the wastewater infrastructure, consisting of wastewater sourced from households to the management system. Wastewater in this study refers to wastewater in the form of sewage water (black water).

\section{Material and Methods}

\subsection{Material}

Domestic wastewater comes from residential activities, houses, apartments, offices, businesses and so on with an average flow of wastewater varies according to the designation and region [8]. According to [9], domestic wastewater flow is categorized in residential areas, institutional areas, commercial areas and recreation areas. Domestic wastewater treatment system is a series of domestic wastewater management activities in a single unit with domestic wastewater management infrastructure and facilities.

Domestic wastewater treatment system is divided into two management systems, namely Local/On-site and Centralized/Off-site. Off-site domestic wastewater treatment system is a management system that is carried out by draining domestic wastewater from sources collectively to a centralized treatment sub-system to be treated before it is discharged into water bodies [8]. Off-site domestic wastewater treatment system is divided into settlement scale, specific area scale and urban scale. This system has complete services including wastewater treatment plan (WWTP), primary pipe, secondary pipe, tertiary pipe, pumping station (depending on needs) and relative range over a wide area. In selecting options between the on-site or off-site domestic wastewater treatment system, 5 factors [8] as listed in Table 1 should be considered.

Table 1. Domestic Wastewater Treatment System Type Selection Factors

\begin{tabular}{clcc}
\hline No & \multicolumn{1}{c}{ Parameter } & \multicolumn{2}{c}{ Criteria } \\
\cline { 3 - 4 } & & On-Site & Off-Site \\
\hline 1 & $\begin{array}{l}\text { Population } \\
\text { Density }\end{array}$ & $\begin{array}{c}<150 \\
\text { People/ha }\end{array}$ & $>150$ People/ha \\
\hline 2 & $\begin{array}{l}\text { GroundwaterLevel } \\
\text { Depth }\end{array}$ & $>2$ meters & $<2$ meters \\
\hline 3 & Soil Permeability & $<5 \times 10^{-4}$ & $>5 \times 10^{-4}$ \\
\hline 4 & Financing Ability & Capable & Capable \\
\hline 5 & Land Slope & $0 \%$ or flat & $<2 \%$ \\
\hline
\end{tabular}

Settlement,

$>2 \%$ Urban

Source: Minister For Public Works and Human Settlements, 2017

The amount of wastewater in residential areas is generated from $60-80 \%$ of the use of clean water. In planning the amount of water generation, it is need to calculate the design discharge $\left(\mathrm{Q}_{\text {design }}\right)$ which is the sum of the peak discharge $\left(\mathrm{Q}_{\text {peak }}\right)$ and infiltration discharge $\left(\mathrm{Q}_{\text {Inf }}\right)$, with the equation as follows:

$$
\begin{aligned}
& \mathrm{Q}_{\mathrm{r}} \quad=(\text { range } 60-80 \%) \times \text { Volume of drinking } \\
& \text { water consumption } \times \mathrm{p} \\
& \mathrm{Q}_{\text {min }} \quad=\left(1 / 5 \times(\mathrm{p} / 1000)^{0,2} \times \mathrm{Q}_{\mathrm{r}}\right. \\
& \mathrm{Q}_{\text {peak }} \quad=\mathrm{Q}_{\mathrm{r}} \times \text { peak factor }(\text { Fig. } 1) \\
& \mathrm{Q}_{\mathrm{Inf}} \quad=\frac{\text { Area (ha) } \times \text { peak factor (Fig 2) }}{86400} \\
& \mathrm{Q}_{\mathrm{d}} \quad=\mathrm{Q} \text { peak }+\mathrm{Q} \text { Infiltration }
\end{aligned}
$$

Information,

$$
\begin{aligned}
& \mathrm{Q}_{\mathrm{r}} \quad=\text { Amount of wastewater }\left(\mathrm{m}^{3} / \text { day }\right) \\
& \mathrm{p} \quad=\text { Total population (people) } \\
& \mathrm{Q}_{\min } \quad=\text { Minimum wastewater discharge } \\
& \left(\mathrm{m}^{3} / \text { day }\right) \\
& \mathrm{Q}_{\text {peak }}=\text { Peak wastewater discharge }\left(\mathrm{m}^{3} / \text { day }\right) \\
& \mathrm{Q}_{\text {inf }} \quad=\text { Infiltration discharge of groundwater } \\
& \text { and rainwater }\left(\mathrm{m}^{3} / \text { day }\right) \\
& \mathrm{Q}_{\mathrm{d}} \quad=\text { Design wastewater discharge } \\
& \left(\mathrm{m}^{3} / \text { day }\right)
\end{aligned}
$$

Calculation of peak wastewater discharge and infiltration discharge need to be multiplied by the peak factor that refers to Figure 1 and Figure 2.

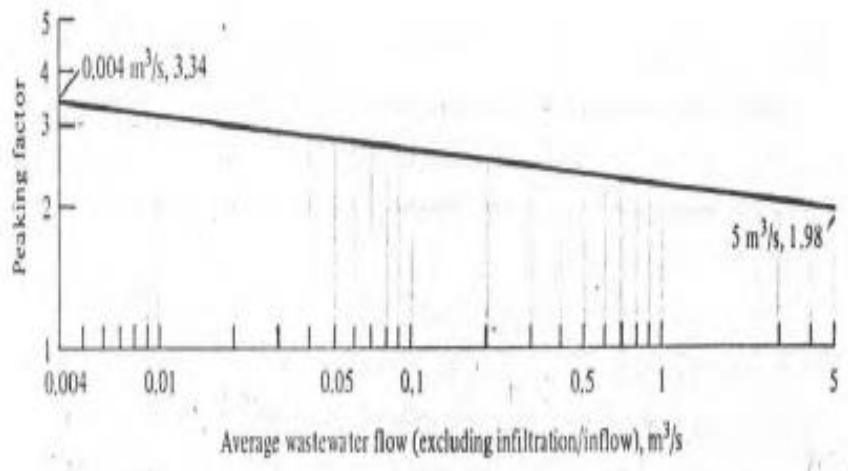

Figure 1. Peaking Factor for Domestic Wastewater Flows

Wastewater flow in the piping system is attempted using the gravity flow method for consideration of efficiency by engineered the pipe slope. Pipes must be designed in a half-full condition considering the required air space and anticipation if a maximum discharge occurs. For partial / half-full flow, the flow rate of wastewater must be in the range of 0.6 $\mathrm{m} / \mathrm{sec}-3 \mathrm{~m} / \mathrm{sec}$ with an assumption of $\mathrm{d} / \mathrm{D}$ 0.6-0.8. In addition, the use of piping materials will also affect the velocity of flow through roughness values (n). 


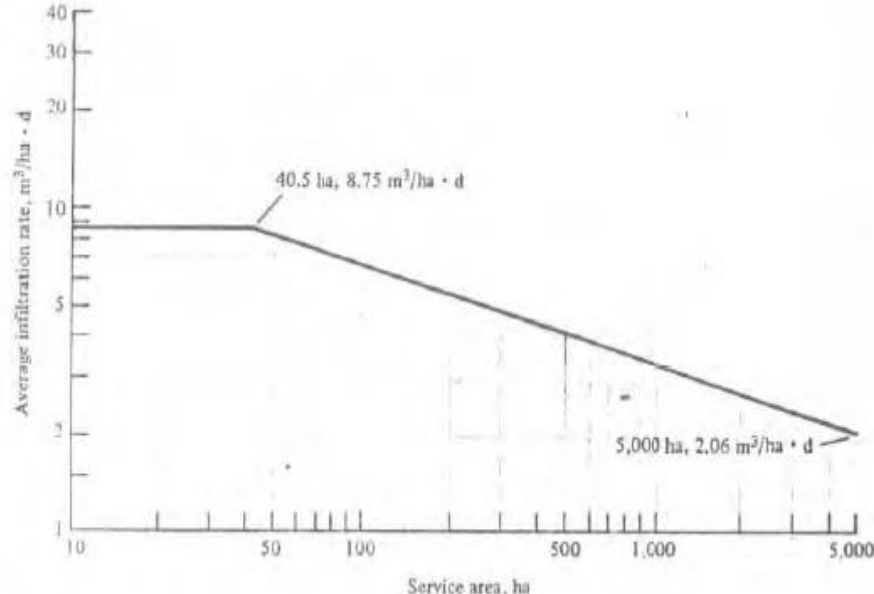

Figure 2. Average Infiltration Rate Allowance for New Sewer

According to the Detailed Engineering Planning Guidelines [10] there are several stages in planning a piping network system referring to the Planning Guidelines, as follows:

(1) Determine the value of the ratio d / D, (between 0.6 - 0.8). The value of $\mathrm{d} / \mathrm{D}$ is the difference between the wet height and the diameter of the pipe used.

(2) Determine the values of $Q_{p} / Q_{f}$ and $V_{p} / V_{f}$, by using the graphical reading of the hydraulic elements (Figure 3) which refers to the value of $\mathrm{d} / \mathrm{D} . \mathrm{Q}_{\mathrm{p}}$ is a discharge of partial flow and $\mathrm{Q}_{\mathrm{f}}$ is a discharge of full flow.

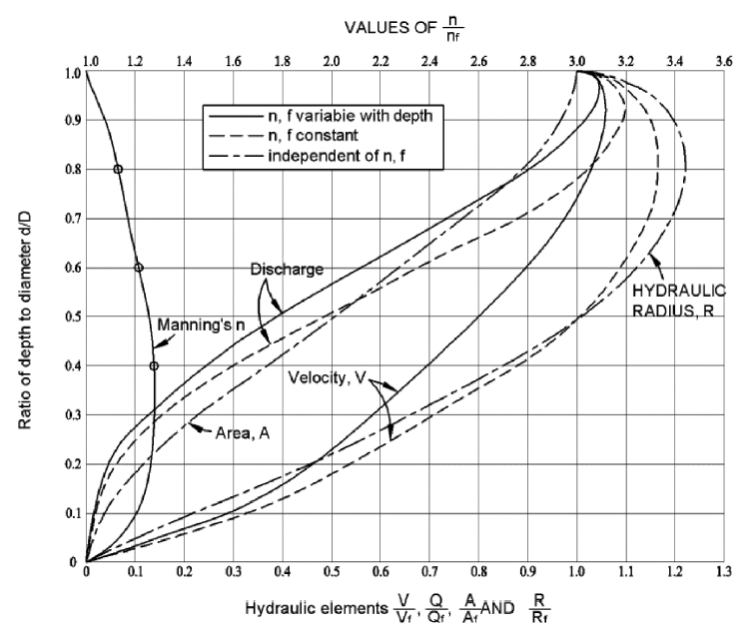

Figure 3. Hydraulic Element Graph

(3) Determine the roughness value (n) of the pipe, based on the type of pipe material used

(4) Determine the slope of the channel, with the equation:

$$
\begin{array}{ll}
\mathrm{S} & =\left(\mathrm{h}_{1}-\mathrm{h}_{0}\right) / \mathrm{L} \\
\mathrm{S}_{\text {minimum }} & =0.01 \times \mathrm{Q}_{\mathrm{d}}{ }^{0.667}
\end{array}
$$

Information,

$$
\begin{array}{ll}
\mathrm{S} & =\text { land slope } \\
\mathrm{h}_{0} & =\text { initial pipe elevation }
\end{array}
$$

$$
\begin{array}{ll}
\mathrm{h}_{1} & =\text { end pipe elevation } \\
\mathrm{S}_{\text {minimum }} & =\text { minimum slope } \\
\mathrm{Q}_{\mathrm{d}} & =\text { design discharge }
\end{array}
$$

(5) Calculate the pipe dimensions needed to be used with the equation:

$\mathrm{d}=\left(\frac{\mathrm{Q}_{\mathrm{d}} \times \mathrm{n}}{0.3118 \times \mathrm{S}^{0.5}}\right)^{3 / 8}$

Check,

$$
\begin{aligned}
& \mathrm{V}_{\mathrm{f}}=\left(\frac{\left(\frac{\mathrm{D}}{4}\right)^{0.67} \times \mathrm{S}^{0.5}}{\mathrm{n}}\right) \\
& \mathrm{V}_{\mathrm{p}}=\mathrm{V}_{\mathrm{p}} / \mathrm{V}_{\mathrm{f}} \times \mathrm{V}_{\mathrm{f}}
\end{aligned}
$$

$$
\begin{aligned}
& \text { Information, } \\
& \begin{array}{ll}
\mathrm{d} & =\text { pipe dimension needed } \\
\mathrm{S} & =\text { slope } \\
\mathrm{n} & =\text { roughness coefficient } \\
\mathrm{V}_{\mathrm{f}} & =\text { full flow speed } \\
\mathrm{V}_{\mathrm{p}} & =\text { partial flow speed }
\end{array}
\end{aligned}
$$

In the piping system, a control tub that functions as a control of sewerage is needed. Control tubs are placed at each change in diameter, slope, and pipe assembly. On a straight control tubs, they are placed every 50-70 meters. WWTP buildings at settlement scale generally use anaerobic processing with efficiency considerations. The processing component consists of two tanks, namely an initial settling tank and an aerobic filter tub. Each tank is expected to reduce the hazardous substances that are processed in accordance with environmental quality standards, namely BOD $30 \mathrm{mg} / \mathrm{L}$, COD $100 \mathrm{mg} / \mathrm{L}$ and TSS 30 $\mathrm{ml} / \mathrm{L}$ [11].

Calculation of WWTP building needs through four stages as follows:

(1) Calculation of organic reduction, to determine the percentage of removal and COD / BOD / TSS out levels, with the equation,

(2) Calculation of the volume of sludge, to determine the cubically of the amount of sludge produced,

(3) Calculation of the volume of the tub to determine the cubically of the tub against the sludge produced,

(4) Calculation of tub dimensions to determine the appropriate tub dimensions based on the percentage of organic removal, sludge volume and volume of tubs, with the equation.

Table 2. WWTP Building Planning Criteria

\begin{tabular}{l}
\hline I. Sedimentation Tub Design Criteria \\
\hline - Retention time in the settling room, \\
$\mathrm{T}_{\mathrm{d}}=2-5$ hours. \\
- Depth of settling, $\mathrm{H}=1,5-4 \mathrm{~m}$ \\
- Surface Load, SLR $=30-50 \mathrm{~m}^{3} / \mathrm{m}^{2}$.day \\
- BOD removal efficiency $=25 \%$ \\
\hline II. Design Criteria for Aerobic Filter Tub \\
\hline - Retention time in the settling room, \\
$\mathrm{T}_{\mathrm{d}}=6-8$ hours. \\
- Up-Flow Velocity (V up) $\leq 2 \mathrm{~m} /$ hour
\end{tabular}


- Organic Load $<4 \mathrm{~kg} \mathrm{COD} / \mathrm{m}^{3}$.day

- BOD removal efficiency BOD 70-90\%

- High Bed Microbial Breeding Media $0.9-1.5 \mathrm{~m}$

- High Water Above Media Bed $20 \mathrm{~cm}$

- The surface area of the media filter media volume unity $=90-300 \mathrm{~m}^{2} / \mathrm{m}^{3}$ media

Check,

$\mathrm{T}_{\mathrm{d}}=(\operatorname{vol} 1 \times \mathrm{w} \times \mathrm{h} / \mathrm{Q}) \times 24$ hours

Source: Detailed Engineering Planning Guidelines SPALD-T Cipta Karya, 2018

\subsection{Methods}

This study was conducted in the Muara Lawai Village which is the village with the highest number of poor and near poor people out of the 16 Villages in the District of Muara Enim and still included in the category of underdeveloped Villages [12]. Geographically, the residential areas in the Muara Lawai village are centered on the river banks which is susceptive to pollute the river. Figure 4 shows the distribution of settlements in Muara Lawai Village

Table 3. Population of Muara Lawai Village

\begin{tabular}{ccccc}
\hline \multirow{2}{*}{ Village } & \multicolumn{2}{c}{ Total Population } & \multicolumn{2}{c}{$\begin{array}{c}\text { Population Welfare } \\
\text { Status } \\
\text { 40\% Lowest Group }\end{array}$} \\
\cline { 2 - 5 } & $\begin{array}{c}\text { Number } \\
\text { of People }\end{array}$ & $\begin{array}{c}\text { Number of } \\
\text { Household }\end{array}$ & $\begin{array}{c}\text { Number } \\
\text { of People }\end{array}$ & $\begin{array}{c}\text { Numberof } \\
\text { Household }\end{array}$ \\
\hline Dusun I & 1,036 & 156 & 444 & 116 \\
\hline $\begin{array}{c}\text { Dusun } \\
\text { II }\end{array}$ & 813 & 126 & 348 & 91 \\
\hline $\begin{array}{c}\text { Dusun } \\
\text { III }\end{array}$ & 974 & 150 & 417 & 109 \\
\hline Total & 2,823 & 436 & 1,210 & 316 \\
\hline $\begin{array}{l}\text { Source : Central Bureau of Statistics } \\
\text { Muara Enim, 2018 }\end{array}$
\end{tabular}

The sampling method was used a random sampling method that is done randomly without regard to the existing status in the population. The number of sample questionnaires using the Slovin formula with a $90 \%$ confidence level and a sampling error of $10 \%$, so the formula used is:

$$
\begin{aligned}
n & =\frac{436}{1+436(0.1)^{2}} \\
& =81.34=81 \text { Households }
\end{aligned}
$$

Based on calculations, the total sample taken is 81 households in areas with high population density with considered the conditions in the area.

The data needed for this study is divided into primary data and secondary data. Primary data is the existing condition data obtained from the questionnaire, by counting the number of samples based on the number of people in Muara Lawai Village with 2,823 people or 436 households [4] which is centralized in one location, which is the river bank.

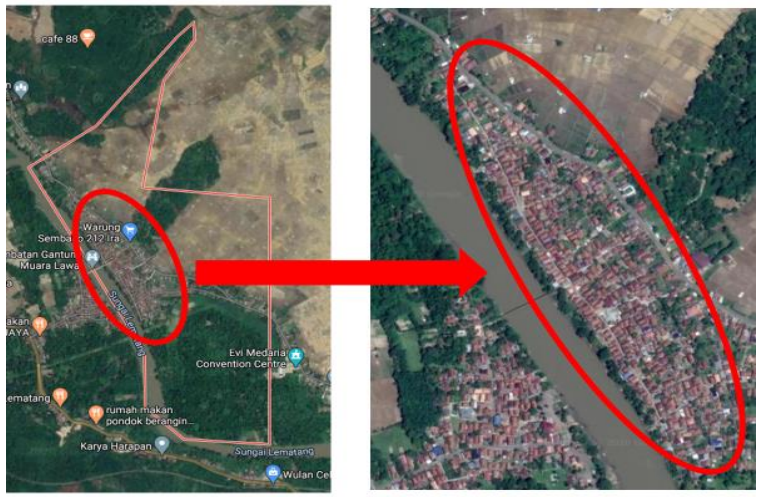

Figure 4. Distribution of Settlements in Muara Lawai Village

\begin{tabular}{|c|c|c|}
\hline No & Aspect & Variable \\
\hline A & \multicolumn{2}{|c|}{ Existing Condition Analysis Variables } \\
\hline \multirow[t]{7}{*}{1} & \multirow{7}{*}{$\begin{array}{l}\text { Residential } \\
\text { Building Data }\end{array}$} & Building Type \\
\hline & & Number of Building Users \\
\hline & & Building Status \\
\hline & & Number of Latrines \\
\hline & & Number of Septic Tank \\
\hline & & Drinking Water Source \\
\hline & & Electrical connection \\
\hline \multirow[t]{2}{*}{2} & \multirow[t]{2}{*}{ Accessibility } & Home Access Road Conditions \\
\hline & & $\begin{array}{l}\text { Vehicle Parking Distance to the } \\
\text { Septic Tank Hole }\end{array}$ \\
\hline \multirow[t]{8}{*}{3} & \multirow{8}{*}{$\begin{array}{l}\text { Septic Tank } \\
\text { Conditions }\end{array}$} & Septic Tank Position \\
\hline & & Time of Construction \\
\hline & & Last Suction Time \\
\hline & & Septic Tank Type \\
\hline & & Septic Tank Material \\
\hline & & Septic Tank Base \\
\hline & & Air Pipe / Ventilation \\
\hline & & Suction Hole \\
\hline \multirow[t]{2}{*}{4} & \multirow[t]{2}{*}{ Financial } & $\begin{array}{l}\text { Total Household Income Per } \\
\text { Month }\end{array}$ \\
\hline & & $\begin{array}{l}\text { Ability / Willingness to Build a } \\
\text { Septic Tank }\end{array}$ \\
\hline B & \multicolumn{2}{|c|}{$\begin{array}{l}\text { Domestic Wastewater Treatment System } \\
\text { Development Planning Analysis }\end{array}$} \\
\hline \multirow[t]{5}{*}{5} & \multirow{5}{*}{$\begin{array}{l}\text { Domestic } \\
\text { Wastewater } \\
\text { Treatment } \\
\text { System Type } \\
\text { Selection }\end{array}$} & Population density \\
\hline & & Groundwater Surface Depth \\
\hline & & Land Slope \\
\hline & & Soil Permeability \\
\hline & & Financing Ability \\
\hline \multirow[t]{4}{*}{6} & \multirow{4}{*}{$\begin{array}{l}\text { Technical } \\
\text { Calculation }\end{array}$} & Amount of Wastewater (Debit) \\
\hline & & Hydrolysis radius \\
\hline & & Waste Flow Speed \\
\hline & & Wastewater Delay Time \\
\hline
\end{tabular}

Table 4. Research Variables 
The stages in this study include data collection (primary data through questionnaire surveys, secondary data through the results of literature studies), as well as data recapitulation and analysis. The questionnaire was prepared based on variables processed from various references, previous research studies, forum group discussion (FGD) and applicable regulations which were then grouped into two groups, namely the existing condition analysis variable which would describe the existing conditions of the research area and the planning analysis variables that would be used for domestic wastewater treatment system development planning in the study area (see Table 4).

\section{Results and Discussions}

\subsection{Existing Condition}

In residential buildings aspect, there are $100 \%$ of respondents who privately owned residential building with an average number of lives per building 4.7 people, the average number of latrines and the number of septic tanks is 1 unit per household, $32.10 \%$ accessing drinking water from other source which is in this case is from river, $72.84 \%$ use electricity connection of 450 watts. Electricity connection is one of the benchmarks for the level of community welfare which indicates that population in Muara Lawai Village is dominated by household with a low-income community or LIC.

In the accessibility aspect, there were only $39.51 \%$ of respondents who had a house to be accessed by large vehicles / trucks and had a safe parking space for desludging into household septic tanks with a distance of less than $10 \mathrm{~m}$.

In the aspect of septic tanks, that $88.89 \%$ of respondents do not know when the exact time of construction of a septic tank. As many as $100 \%$ have placed their septic tanks outside the house building with $88.89 \%$ non-fabricated septic tank types consisting of $58.33 \%$ made of concrete material and $41.67 \%$ made of masonry. As many as $96.30 \%$ of septic tanks have air holes and suction holes, but $100 \%$ of respondents stated that since they were built, they have never carried out a septic tank until now. This indicates that the lack of maintenance by the community could even make it possible for existing septic tanks to be built or built not to meet the standards and can pollute the soil and ground water considering the results of $88.89 \%$ of respondents stated that the built-in septic tank was not impermeable.

In the aspect of financial condition, there are $27.16 \%$ of non-low-income communities (Non-MBR) and $72.84 \%$ of low-income communities (MBR) categories of $20.90 \%$ earning < IDR 1 million and $51.85 \%$ between IDR $1-2$ million. However, $75.30 \%$ of the community stated that they have the ability to build septic tanks. So that the respondents have the ability and desire to have a proper and safe septic latrine.
With all the above conditions described in the Table 5, it showed that the existing condition of the wastewater sanitation infrastructure are not feasible and safe yet, given the condition of the septic tank which is not impermeable and has never been treated with routine suction and scheduled due to septic tank conditions that do not meet standards.

\subsection{Selection of Domestic Wastewater Treatment Systems}

According to [8], there are several criteria in the selection of the type of on-site domestic wastewater treatment system or off-site domestic wastewater treatment system by considering various factors. Comparison of existing conditions to the selection criteria for sanitation type are summarized in Table 6. Therefore, it can be concluded that system that can be built in the research area is used off-site domestic wastewater treatment system.

\subsection{Planning of Domestic Wastewater Treatment System dan Technical Design}

\subsubsection{Calculation of Wastewater}

Analysis of the calculation of wastewater is needed to find out the amount of wastewater produced by residents in Muara Lawai Village. The number of households in the domestic wastewater treatment system planning at this research is targeted at 41 households with a total of 205 people. This coverage is based on the results of field observations on the availability of land for WWTP locations that are most likely to be implemented. Based on the results of calculations using equations 15 , the total amount of wastewater generated is recapitulated in Table 7.

Table 7. The Recapitulation Table of Wastewater Calculation

\begin{tabular}{|c|c|c|}
\hline $\begin{array}{l}\text { Calculation of } \\
\text { Wastewater }\end{array}$ & $\begin{array}{l}\text { Calculation for } \\
\text { Each Household }\end{array}$ & $\begin{array}{l}\text { Calculation for All } \\
\text { Households }\end{array}$ \\
\hline $\begin{array}{l}\text { Amount of } \\
\text { wastewater } \\
\text { per people }\end{array}$ & $\begin{array}{l}80 \\
\text { liter/day/people }\end{array}$ & 80 liter/day/people \\
\hline $\begin{array}{l}\text { Total of } \\
\text { wastewater } \\
\text { discharge } \\
\left(\mathrm{Q}_{\text {wastewater }}\right)\end{array}$ & $\begin{array}{l}0.4 \mathrm{~m}^{3} / \text { day or } \\
0.000005 \mathrm{~m}^{3} / \mathrm{s}\end{array}$ & $\begin{array}{l}16.4 \mathrm{~m}^{3} / \text { day or } \\
0.00019 \mathrm{~m}^{3} / \mathrm{s}\end{array}$ \\
\hline $\begin{array}{l}\text { Minimum } \\
\text { total of } \\
\text { wastewater } \\
\text { discharge } \\
\left(\mathrm{Q}_{\text {min }}\right)\end{array}$ & $\begin{array}{l}0.03 \mathrm{~m}^{3} / \text { day or } \\
0.0000003 \mathrm{~m}^{3} / \mathrm{s}\end{array}$ & $\begin{array}{l}2.33 \mathrm{~m}^{3} / \text { day or } \\
0.000027 \mathrm{~m}^{3} / \mathrm{s}\end{array}$ \\
\hline $\begin{array}{l}\text { Maximum } \\
\text { total of } \\
\text { wastewater } \\
\text { discharge } \\
\left(Q_{\text {peak }}\right)\end{array}$ & $\begin{array}{l}1.34 \mathrm{~m}^{3} / \text { day or } \\
0.000015 \mathrm{~m}^{3} / \mathrm{s}\end{array}$ & $\begin{array}{l}54.82 \mathrm{~m}^{3} / \text { day or } \\
0.0006346 \mathrm{~m}^{3} / \mathrm{s}\end{array}$ \\
\hline $\begin{array}{l}\text { Total of } \\
\text { infiltration }\end{array}$ & $\begin{array}{l}0,33 \mathrm{~m}^{3} / \text { day or } \\
0,000004 \mathrm{~m}^{3} / \mathrm{s}\end{array}$ & $\begin{array}{l}12,96 \mathrm{~m}^{3} / \text { day or } \\
0,00015 \mathrm{~m}^{3} / \mathrm{s}\end{array}$ \\
\hline
\end{tabular}




\section{discharge}

$\left(Q_{\text {infiltrasi }}\right)$

Total of

design

$1.66 \mathrm{~m}^{3} /$ day or

$0.000019 \mathrm{~m}^{3} / \mathrm{s}$

$67.78 \mathrm{~m}^{3} /$ day or

discharge

$\left(\mathrm{Q}_{\text {design }}\right)$

Source : Data Analysis

\subsubsection{Calculation of Piping System}

The pipeline network system calculation refers to the Detailed Engineering Planning Guidelines [10] with several calculation phases that have been explained previously. In detail, the calculation for one of the pipes (pipe number 1) as follows:

(1) Ratio d / D, determined at $80 \%$ or 0.80

(2) $\mathrm{Q}_{\mathrm{p}} / \mathrm{Q}_{\mathrm{f}}$ value $=1.02$ (based on the hydraulic element chart (Figure 3) with reference to the value $\mathrm{d} / \mathrm{D})$

$$
\mathrm{Q}_{\mathrm{f}}=\mathrm{Q}_{\mathrm{d}} /\left(\mathrm{Q}_{\mathrm{p}} / \mathrm{Q}_{\mathrm{f}}\right)=0.000019 / 1.02=0.0002 \mathrm{~m}^{3} / \mathrm{s}
$$

(3) Pipe roughness value (n) $=0.012$ (waste PVC material)

(4) Channel Slope uses equation 6;

$$
\begin{aligned}
\mathrm{S} & =\frac{\mathrm{h}_{1}-\mathrm{h}_{0}}{\mathrm{~L}} \\
& =\frac{0.64 \mathrm{~m}-0.60 \mathrm{~m}}{6.2 \mathrm{~m}} \\
& =0.007 \mathrm{~m} / \mathrm{m} \\
\mathrm{S}_{\text {minimum }} & =0.01 \times \mathrm{Q}_{\mathrm{d}} 0.667 \\
& =0.01 \times 0.00019^{0.667} \\
& =0.000032
\end{aligned}
$$

(5) Calculation of the pipe dimension to be used with equation 8 :

$$
\begin{aligned}
\mathrm{d} & =\left(\frac{\mathrm{Q}_{d} \times n}{0.3118 \times \mathrm{S}^{0.5}}\right)^{3 / 8} \\
& =\left(\frac{0.00019 \times 0.012}{0.3118 \times(0.000032)^{0.5}}\right)^{3 / 8}=0.082 \mathrm{~m}
\end{aligned}
$$

On the market $0.10 \mathrm{~m}$ or $4^{\prime \prime}$ (hence, used in accordance with the market)

Control checks using equation 9:

$$
\begin{aligned}
\mathrm{V}_{\mathrm{f}} & =\left(\frac{\left(\frac{\mathrm{D}}{4}\right)^{0.67} \times \mathrm{S}^{0.5}}{\mathrm{n}}\right) \\
& =\left(\frac{\left(\frac{0.10}{4}\right)^{0.67} \times 0.007^{0.5}}{0.012}\right) \\
& =0.59 \mathrm{~m} / \mathrm{s}
\end{aligned}
$$

$\mathrm{V}_{\mathrm{p}} / \mathrm{V}_{\mathrm{f}}=1.17 \mathrm{~m} / \mathrm{sec}$ (based on the hydraulic element graph (figure 3) with reference to the value

\begin{tabular}{|c|c|c|c|}
\hline No & Aspect & Variable & Existing Condition \\
\hline \multirow{7}{*}{1} & \multirow{7}{*}{$\begin{array}{c}\text { Residential Building } \\
\text { Data }\end{array}$} & Building Type & $100 \%$ private residence \\
\hline & & Number of Building Users & average 4.7 people/household \\
\hline & & Building Status & $100 \%$ privately owned \\
\hline & & Number of Latrines & $100 \%$ have 1 unit/household \\
\hline & & Number of Septic Tank & $\begin{array}{l}100 \% \text { have a septic tank with } 1 \text { unit / } \\
\text { household }\end{array}$ \\
\hline & & Drinking Water Source & $32.10 \%$ from river \\
\hline & & Electrical connection & $72.84 \%$ use 450 watt \\
\hline \multirow[b]{2}{*}{2} & \multirow[b]{2}{*}{ Accessibility } & Home Access Road Conditions & $39.51 \%$ accessed by large vehicles \\
\hline & & $\begin{array}{l}\text { Vehicle Parking Distance to the Septic } \\
\text { Tank Hole }\end{array}$ & $27.16 \%>30$ meters \\
\hline \multirow{8}{*}{3} & \multirow{8}{*}{$\begin{array}{l}\text { Septic Tank } \\
\text { Conditions }\end{array}$} & Septic Tank Position & $100 \%$ outside building \\
\hline & & Time of Construction & $88.89 \%$ do not know \\
\hline & & Last Suction Time & $100 \%$ never carried out \\
\hline & & Septic Tank Type & $88.89 \%$ non-fabricated septic tank \\
\hline & & Septic Tank Material & $41.67 \%$ made of masonry \\
\hline & & Septic Tank Base & $88.89 \%$ not impermeable \\
\hline & & Air Pipe / Ventilation & $3.70 \%$ no air holes \\
\hline & & Suction Hole & $5.15 \%$ no suction hole \\
\hline \multirow{2}{*}{4} & \multirow{2}{*}{ Financial } & Total Household Income/Month & $72.84 \%$ under 2 million rupiah \\
\hline & & Willingness to Build a Septic Tank & $75.30 \%$ ability to build \\
\hline
\end{tabular}
$\mathrm{d} / \mathrm{D})$, then using equation 10 :

$$
\begin{aligned}
\mathrm{V}_{\mathrm{p}} & =\mathrm{V}_{\mathrm{p}} / \mathrm{V}_{\mathrm{f}} \times \mathrm{V}_{\mathrm{f}} \\
& =1.17 \times 0.59 \mathrm{~m} / \mathrm{sec} \\
& =0.69 \mathrm{~m} / \mathrm{sec}
\end{aligned}
$$

(meet the criteria $0.6-3.0 \mathrm{~m} / \mathrm{sec}$ )

Based on the above calculation results, it has been found that the dimension of the wastewater pipe number 1 with a length of 6.2 meters can use the dimension (d) of a pipe of $100 \mathrm{~mm}$ or 4" made of PVC with a roughness (n) 0.012 , slope (S) 0.007 or $0.7 \%$. Furthermore, calculations and other pipe requirements will be presented in Figure 5.

Table 5. Recapitulation of Existing Wastewater Sanitation Conditions 
Table 6. Comparison of existing conditions to the selection criteria for sanitation type

\begin{tabular}{clcccc}
\hline \multirow{2}{*}{ No } & \multirow{2}{*}{ Parameter } & \multicolumn{2}{c}{ Criteria } & Existing & Choice \\
\cline { 3 - 5 } & & On-Site & Off-Site & \\
1 & Population density & $<150$ people/ha & $>150$ people/ha & 202.65 people/ha & Off-site \\
\hline 2 & Groundwater Level Depth (MAT) & $>2$ meters & $<2$ meters & $1-20$ meters & On-site \\
\hline 3 & Soil Permeability & $<5 \times 10^{-4}$ & $>5 \times 10^{-4}$ & $\begin{array}{c}6.19 \times 10^{-6} \text { (Alluvial } \\
\text { Soil) }\end{array}$ & Off-site \\
\hline 4 & Financing Ability & Capable & Capable & $75.31 \%$ Capable & Off-site \\
\hline 5 & Land Slope & $0 \%$ or flat & $\begin{array}{c}<2 \% \text { settlement } \\
\text { scale, }>2 \% \text { urban } \\
\text { scale }\end{array}$ & $0-2 \%$ & $\begin{array}{c}\text { Off-site } \\
\text { settlement } \\
\text { scale }\end{array}$ \\
\hline
\end{tabular}

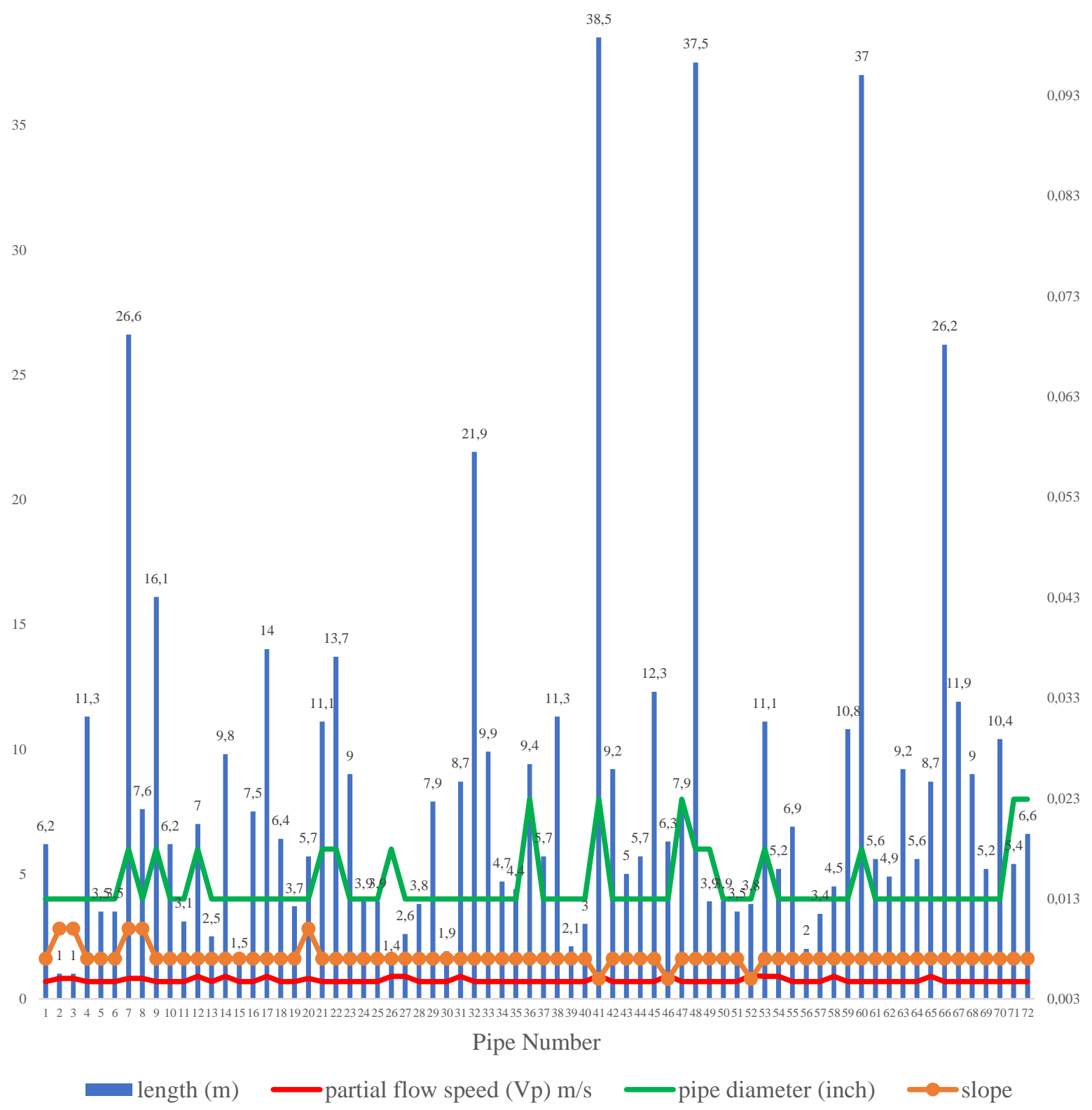

Figure 5. Analysis of Hydraulics Calculations and Need for Pipe Dimensions 


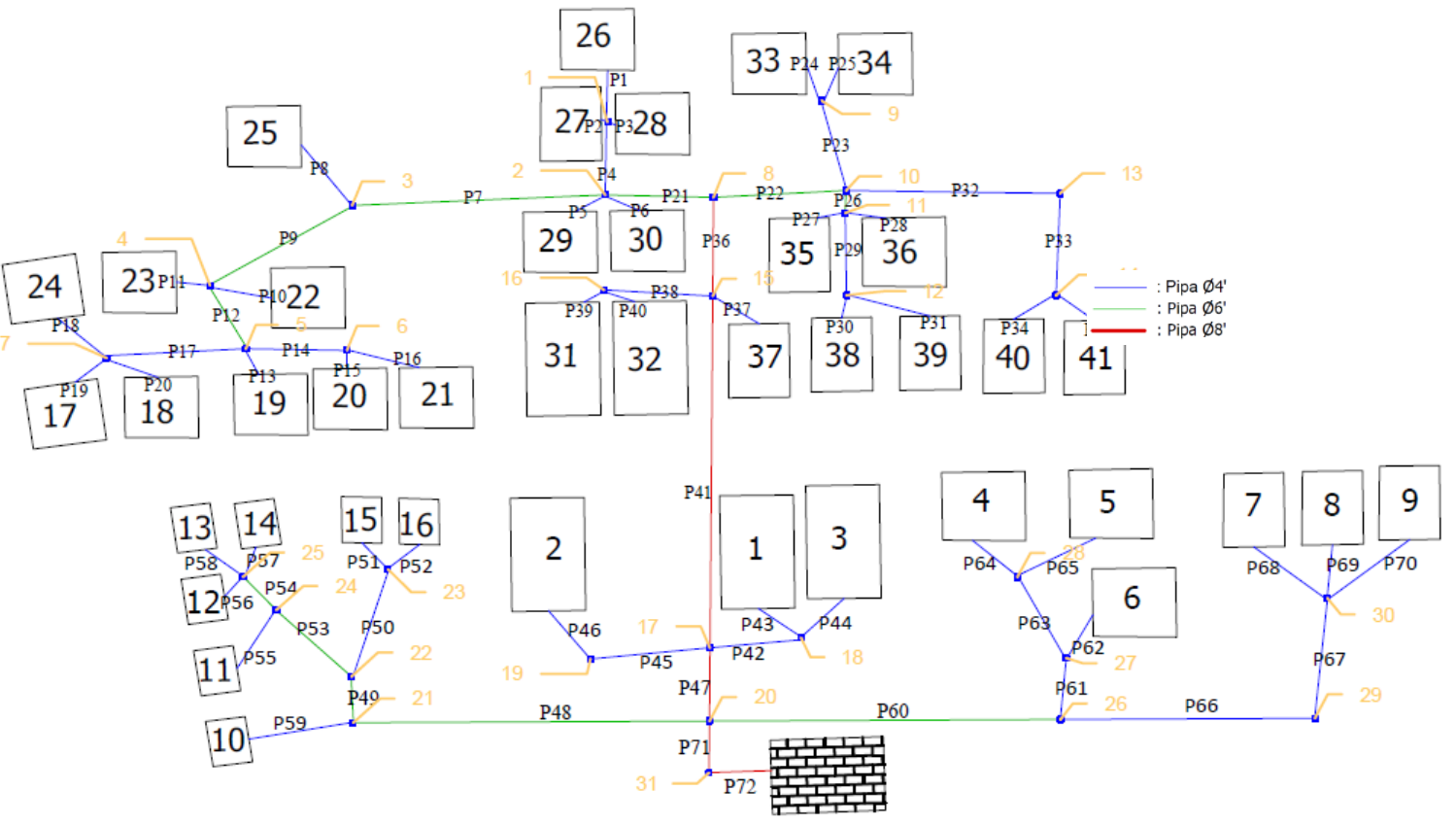

Figure 6. Pipeline Network Scheme Based on Hydraulics Calculation

Based on the calculation and analysis that showed in Figure 5, the speed of wastewater in all pipes is within the speed criteria limit $(\mathrm{V})$ between 0.6 - $3.0 \mathrm{~m} / \mathrm{s}$, has met the applicable standards and criteria. The total length is recapitulated in Table 8 below.

Table 8. Recapitulation of Pipeline Needs

\begin{tabular}{cccc}
\hline Type & $\begin{array}{c}\text { House } \\
\text { Connection }\end{array}$ & Service PipeMain Pipe \\
\hline $\begin{array}{c}\text { Pipe } \\
\text { Roughness } \\
\text { Coefficient (n) }\end{array}$ & 0.012 & 0.012 & 0.012 \\
\hline Slope (S) & $0.7-1 \%$ & $0.7 \%$ & $0.6-$ \\
& & & $0.7 \%$ \\
\hline $\begin{array}{c}\text { Speed of } \\
\text { wastewater in } \\
\text { pipe }\end{array}$ & $0.69-0.82$ & 0.90 & 0.93 \\
V (m/s) & & & \\
\hline Pipe Size & $4^{\prime \prime}$ & $6^{\prime \prime}$ & $8^{\prime \prime}$ \\
\hline Length & $378.4 \mathrm{~m}$ & $167.4 \mathrm{~m}$ & $67.8 \mathrm{~m}$ \\
\hline $\begin{array}{c}\text { Criteria } \\
\text { Standard }\end{array}$ & $\sqrt{ }$ & $\sqrt{ }$ \\
\hline Source: & & & \\
\hline
\end{tabular}

Source : Data Analysis

\subsubsection{Calculations of Complementary Building in the Piping System}

Complementary buildings are supporting structures used to facilitate maintenance and improve the performance of existing drainage systems named a control tank/manhole. The control tank is used to facilitate maintenance of the pipeline in the event of a blockage which is placed at any changes in pipe diameter, pipe slope, flow direction and the meeting of two or more pipelines and it is installed on pipes with straight channels of more than 50-70 meters [8].

Based on the pipeline system calculation and figure (Figure 6), the needs of the control tub are calculated to be 31 units with a size of $50 \times 50 \mathrm{~cm}$. Placement of control tub is only installed at each pipe meeting, considering that each pipe does not exceed $50 \mathrm{~m}$ in length.

\subsubsection{Calculation of WWTP Building Needs}

WWTP buildings is placed at the lowest contour or elevation in the study area, considering the waste flow using the gravity system. Based on observations, locations that were chosen according to criteria were located on vacant land beside the river in Dusun I of Muara Lawai Village. The area of land required for the construction of WWTP depends on the number of houses served, which in this case is targeted at 41 households.

The components of the WWTP Residential Scale are divided into two parts, namely the initial sedimentation tank, and a biofilter with anaerobic system. For the selection of WWTP technology at the settlement scale, it is generally chosen to use Anaerobic processing technology with consideration of efficiency. Anaerobic technology was chosen because it is the simplest technology, does not require large costs and it is easy to operate [13] suitable for residential areas, especially for LIC. The application of anaerobic technology in domestic wastewater management will result in wastewater effluent which is still far below the environmental quality standard [14]. Other advantages of using this technology are simple design, low sludge production, low investment and operational costs and high processing efficiency [15].

Referring to the Off-Site Domestic Wastewater Treatment System Detailed Engineering Planning Guidelines [10], in conducting calculations in each tub there are design criteria that must be referred to (Table 2) and several parameters that must be known and 
determined in advance. The parameters for the BOD in, COD in and TSS in values in the calculation are assumed based on the value of domestic wastewater which generally occurs, namely BOD in of $110 \mathrm{mg} / \mathrm{L}$, COD in of $250 \mathrm{mg} / \mathrm{L}$ and TSS in of $120 \mathrm{mg} / \mathrm{L}$ [16].

Calculation of Settlement Tub

Parameters:

- Total Design discharge $\left(\mathrm{Q}_{\text {design }}\right)=67.78 \mathrm{~m}^{3} / \mathrm{hr}$

- BOD in $=110 \mathrm{mg} / \mathrm{L}$

- COD in $=250 \mathrm{mg} / \mathrm{L}$

- TSS in $=120 \mathrm{mg} / \mathrm{L}$

- $\mathrm{SS} / \mathrm{COD}$ ratio $(0.35-0.45) \quad=0.42$

- Drain intervals (Ip) $\quad=2$ years

- Tub width plan $(\mathrm{w}) \quad=2 \mathrm{~m}$

- Tub height plan $\left(\mathrm{H}_{\mathrm{tub}}\right) \quad=2.5 \mathrm{~m}$

- Water depth plan $\left(\mathrm{H}_{\text {water }}\right) \quad=2.3 \mathrm{~m}$

- Freeboard height $\quad=0.2 \mathrm{~m}$

Based on calculations, the dimensions of the sedimentation tank needed are 3 meters long $\times 2$ meters wide $\times 2.5$ meters high (Figure 7 ). In the process of sedimentation tank management, COD can be reduced from $250 \mathrm{mg} / 1$ to $188.75 \mathrm{mg} / \mathrm{L}$ or by $24.5 \%$, and BOD can be reduced from $110 \mathrm{mg} / 1$ to $81.43 \mathrm{mg} / \mathrm{L}$ or $26 \%$. Drainage in the settling tub is done at intervals every 24 months with the amount of mud volume of $4.62 \mathrm{~m}^{3}$.

Control check:

$\mathrm{T}_{\mathrm{d}} \quad=(\mathrm{Vol} 1 \times \mathrm{w} \times \mathrm{h} / \mathrm{Q}) \times 24$ hour

$=\left((3 \times 2 \times 2.2) / 67.78 \mathrm{~m}^{3}\right) \times 24$

$=5$ hours (meet the criteria)

Calculation of Aerobic Filter Tub

Parameters:
- Design discharge $\left(\mathrm{Q}_{\text {design }}\right) \quad=67.78 \mathrm{~m}^{3} / \mathrm{hr}$

- BOD in $\quad=81.43 \mathrm{mg} / \mathrm{L}$

- COD in $\quad=188.75 \mathrm{mg} / \mathrm{L}$

- Lowest temperature $\quad=28 \mathrm{C}$

- SS/COD Ratio (0.35-0.45) $=0.42$

- Drain intervals (Ip) = 2 years

- Compartment Width (w) $=2 \mathrm{~m}$

- Compartment length (1) $=2.5 \mathrm{~m}$

- Number of compartment $=3 \mathrm{pcs}$

- Systhesis Yield in Anaerob (Y) $=0.06$

Based on calculation above, the dimensions of each compartment in the anaerobic filter is 1.5 meters long $\times 2$ meters wide $\times 2.5$ meters high (Figure 7). Total compartments used are 3 pieces, so the total dimensions needed are length (l) 4.5 meters $\times$ width (w) 2 meters $\times$ height (h) 2.5 meters.

Control check:

$\mathrm{T}_{\mathrm{d}} \quad=(\operatorname{Vol}(1 \times \mathrm{w} \times \mathrm{h}) / \mathrm{Q}) \times 24$ hour

$=\left((4.5 \times 2 \times 2.5) / 67.78 \mathrm{~m}^{3}\right) \times 24$

$=7$ hours (meet the criteria)

Drainage in the anaerobic filter is done at intervals every 24 months with the amount of mud volume of $14.67 \mathrm{~m}^{3}$. In the process of anaerobic filter body management, COD can be reduced from 188.75 $\mathrm{mg} / \mathrm{L} \mathrm{mg} / 1$ to $36.81 \mathrm{mg} / \mathrm{L}$ or $80.5 \%$ and BOD can be reduced from $110 \mathrm{mg} / 1$ to $10.96 \mathrm{mg} / \mathrm{L}$ or $86.54 \%$. The removal efficiency value on the COD and BOD parameters has met the quality standard for domestic wastewater, namely the COD value $<100 \mathrm{mg} / \mathrm{L}$ and the BOD value $<40 \mathrm{mg} / \mathrm{L} \mathrm{[11]. \quad The} \mathrm{amount} \mathrm{of}$ percentage reduction is also the same as the parameters studied using similar technology, around $70-91 \%$ [17].

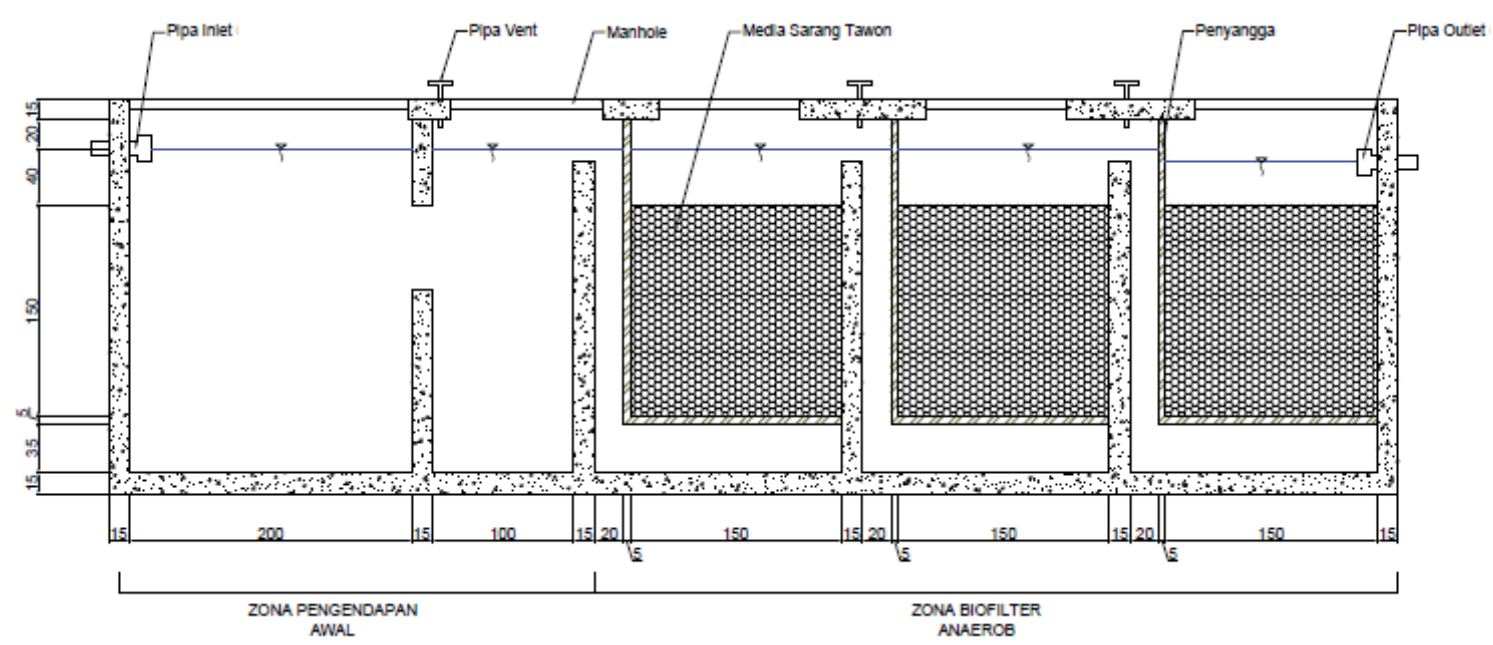

Figure 7. Dimension of Waste Water Treatment Plant (WWTP) 


\section{Conclusion}

From the study it can be concluded that the existing condition of the wastewater sanitation infrastructure facilities in the Muara Lawai Village so far has not been feasible and safe, due to unsuitable septic tanks and $100 \%$ of households have never done desludging. This condition was not only for the MBR category, but $95.45 \%$ of the Non-MBR also did not yet have a safe and impervious septic tank. So that proper and safe sanitation is not necessarily directly proportional to the level of welfare/economy, especially in the study area. The appropriate wastewater management system to be implemented in Muara Lawai Village is the off-site domestic wastewater treatment system.

Provision of off-site domestic wastewater treatment system consists of Service Sub-System (Piping System) and Processing Sub-System (WWTP Building). Wastewater treatment system service coverage targeted into 41 households or 205 people with the average amount of wastewater generation $\left(\mathrm{Q}_{\mathrm{r}}\right)$ $16.40 \mathrm{~m}^{3} /$ day, peak discharge $\left(Q_{\text {peak }}\right) 54.82 \mathrm{~m}^{3} /$ day, minimum discharge $\left(\mathrm{Q}_{\min }\right) 2.33 \mathrm{~m}^{3} /$ day and infiltration

[1] Ministry of Public Works. Minister of Public Works Regulation No. 01 Year 2014 concerning Minimum Service Standards for Public Works and Spatial Planning. 2014. Ministry of Public Works.

[2] M. L. McKenna et al. Human Intestinal Parasite Burden and Poor Sanitation in Rural Alabama. American Journal of Tropical Medicine and Hygiene. 2017, doi: 10.4269/ajtmh.17-0396. pp 1623-1628.

[3] C. Cossio, J. Norrman, J. McConville, A. Mercado, and S. Rauch. Indicators for sustainability assessment of small-scale wastewater treatment plants in low and lowermiddle income countries. Environmental and Sustainability Indicators. 2020, doi: 10.1016/j.indic.2020.100028. pp1-11

[4] Central Bureau of Statistics Muara Enim. Muara Enim Regency in Figures 2018. 2018. Central Bureau of Statistics Muara Enim

[5] National Team for the Acceleration of Poverty Reduction (TNP2K). Integrated Database Utilization Evaluation Report. 2018. National Team for the Acceleration of Poverty Reduction (TNP2K).

[6] S. Ichwan Prastowo. Efforts to Improve Hygiene Healthy Lifestyle by CommunityBased Sanitation in the Tegalgede Karanganyar Village. Hotelier Journal Politeknik Indonesia Surakarta, vol. 2. 2016. pp. 27-31,

[7] A. Ristiawan, P. Purwono, and A. U. Ulya. Social perspective of domestic wastewater management in Entikong Lama district. Sustinere: Journal of Environment and discharge $\left(\mathrm{Q}_{\text {inf }}\right) 12.96 \mathrm{~m}^{3} / \mathrm{day}$. So that the design is obtained at $67.78 \mathrm{~m}^{3} /$ day.

The Piping System uses PVC waste material with a roughness value of 0.012 . The total length of pipes needed for house connections (size 4") is 378.4 $\mathrm{m}$, the service pipe (size 6") is $167.4 \mathrm{~m}$ and the main pipe (size 8") is $68.8 \mathrm{~m}$. There are 31 units of control tub with $50 \times 50 \mathrm{~cm}$ dimension installed at each pipeline meeting.

The treatment system (WWTP Building) uses anaerobic biofilter technology with the overall dimensions of the WWTP building of $7.5 \times 2.0 \times 2.5$ $\mathrm{m}$ divided into 2 parts, namely the Initial Sedimentation Tank and the Biofilter Tank. Sedimentation tanks measuring $3.0 \times 2.0 \times 2.5 \mathrm{~m}$ with a residence time of 5 hours, reducing $24.50 \%$ COD of waste and 26\% BOD of waste. Drain interval every 24 months with a total amount of mud $4.62 \mathrm{~m}^{3}$. The anaerobic filter is $4.5 \times 2.0 \times 2.5 \mathrm{~m}$ with 7 hours of residence time, reducing $80.50 \%$ COD of waste and $86.54 \%$ BOD of waste. Drain interval every 24 months with a total mud volume of $14.67 \mathrm{~m}^{3}$.

\section{References}

Sustainability. 2019, doi: 10.22515/sustinere.jes.v3i2.86.

[8] Minister For Public Works and Human Settlements. Regulation of the Minister of Public Works and Public Housing No. 04 Year 2017 Concerning the Implementation of Domestic Wastewater Treatment Systems. 2017. Minister For Public Works and Human Settlements

[9] G. Tchobanoglous, F. L. Burton, and H. D. Stensel, Wastewater engineering : treatment and reuse. 4th ed. Metcalf \& Eddy, Inc. 2003.

[10] Director General of Cipta Karya Ministry of Public Works and Public Housing. Detailed Engineering Planning Guidelines for Off-Site Domestic Wastewater Treatment System (Series B), vol. B. 2018. Director General of Cipta Karya Ministry of Public Works and Public Housing

[11] Ministry of Environment and Forestry of the Republic of Indonesia. Regulation of the Minister of Environment and Forestry of the Republic of Indonesia No. 68 Year 2016 concerning Domestic Wastewater Quality Standards. 2016. Ministry of Environment and Forestry of the Republic of Indonesia.

[12] Ministry of Villages Development of Underdeveloped Villages and Transmigration of the Republic of Indonesia. Decree of the Director General of Rural Community Development and Empowerment No. 52 of 2018 concerning the Status of Village Progress and Independence. 2018.

[13] Kementerian Pekerjaan Umum dan Perumahan 
Rakyat. Buku 3 Pembangunan Infrastruktur Sanimas IDB. 2018. Kementerian Pekerjaan Umum dan Perumahan Rakyat

[14] Y. V. Afandi and H. R. Sunoko,. Pengelolaan Air Limbah Domestik Komunal Berbasis Masyarakat di Kota Probolinggo. Prosiding Seminar Nasional Pengelolaan Sumberdaya Alam dan Lingkungan 2013, vol. 26, no. 1, 2013. pp. 97-102.

[15] A. G. Liew Abdullah et al. A kinetic study of a membrane anaerobic reactor (MAR) for treatment of sewage sludge," Desalination. 2005, doi: 10.1016/j.desal.2005.03.044.

[16] Environmental Service of Surabaya City Government. Technical Guidance for Hospital Waste Management. 2019. Environmental Service of Surabaya City Government

[17] J. R. Banu, S. Kaliappan, and I. T. Yeom.
Treatment of domestic wastewater using upflow anaerobic sludge blanket reactor. International Journal of Environmental Science and Technology. 2007. doi: 10.1007/BF03326295.

[18] Nur, Muhammad. Analysis of Sanitation Infrastructure Needs in the Musi Riverfront. 2014. Master thesis, Universitas Sriwijaya.

[19] Putri, Dyah Wulandari. Strategies for Developing Domestic Domestic Wastewater Infrastructure for Settlements in Specific Water Areas. 2017. Ph.D. thesis, Institut Teknologi Bandung.

[20] Ministry of Public Works and Public Housing, Director General of Cipta Karya. Technical Guidelines for the Implementation of Sanimas IDB. 2018. Ministry of Public Works and Public Housing, Directorate General of Cipta Karya. 